\title{
RESEARCH PAPER \\ Insect diversity, community composition and damage index on wild and cultivated murtilla
}

\author{
Manuel A. Chacón-Fuentes ${ }^{1,2,3}$, Marcelo G. Lizama ${ }^{1,3,4}$, Leonardo J. Parra ${ }^{1,3}$, \\ Ivette E. Seguel ${ }^{5}$, and Andrés E. Quiroz ${ }^{1,3}$ \\ ${ }^{1}$ Laboratorio de Química Ecológica, Departamento de Ciencias Químicas y Recursos Naturales, \\ Universidad de La Frontera. Ave. Francisco Salazar 01145, Temuco, Chile. \\ ${ }^{2}$ Doctorado en Ciencias de Recursos Naturales, Universidad de La Frontera. Ave. Francisco Salazar 01145, \\ Temuco, Chile. \\ ${ }^{3}$ Centro de Investigación Biotecnológica Aplicada al Medio Ambiente (CIBAMA), Universidad de La \\ Frontera, Av. Francisco Salazar 01145, Casilla 54-D, Temuco, Chile. \\ ${ }^{4}$ Escuela de Agronomía, Universidad Católica de Temuco. Rudecindo Ortega 02950, Temuco, Chile. \\ ${ }^{5}$ Instituto de Investigaciones Agropecuarias, INIA Carillanca. Casilla postal 58-D, Temuco, Chile.
}

\begin{abstract}
M.Chacón-Fuentes, M. Lizama, L. Parra, I. Seguel, A. Quiroz. 2016. Insect diversity, community composition and damage index on wild and cultivated murtilla. Cien. Inv. Agr. 43(1):57-67. Plant domestication is a process in which plants' chemical defenses that help them cope with herbivores might decline. Consequences of this process could be reflected in an increase in insect pests. Therefore, we carried out a survey to contrast the diversity, damage indexes and insect assemblages between cultivated and wild "Murtilla" (Ugni molinae) plants. The main scientific question put forward in this paper is as follows: Is there a decrease in diversity and an increase in both insect assemblages and damage indexes associated with the domestication process in $U$. molinae plants? The objective of this report was to compare the structure of a taxonomic assemblage collected in both wild and cultivated plants and their temporal variation over the year. Seven ecotypes and their respective wild populations were selected for these studies. The results showed higher insect assemblages in wild parents $(77.35 \%)$ vs. cultivated $(22.7 \%)$. The damage indexes were also higher in wild plants $(0.23)$. The diversity indexes according to Margalef (12.98), the Shannon index (5.15) and the Simpson index (19.04) were higher in wild plants. Moreover, approximately 60 species were determinate. We detected changes in insect assemblages, damage and diversity indexes that could suggest that murtilla domestication has altered insect assemblages.
\end{abstract}

Key words: Damage index, domestication, insect diversity, Ugni molinae.

\section{Introduction}

Domestication is a process in which plants go from a wild environment to another environment

Received August 12, 2015. Accepted January 18, 2016. Corresponding author: andres.quiroz@ufrontera.cl in which they are completely dependent on human care for their survival and reproduction (Turcotte et al., 2014). Furthermore, Evans (1993) reported that there are dramatic changes in plants after the domestication process, and these changes could alter the interactions between insect assemblages. Gepts (2014) reported that in the domestication 
process, it is possible that there is a development of a "domestication syndrome", in which fruit size, the number of seeds and plant growth are increased according to human requirements. Nevertheless, this process also decreases the natural barriers of plants, such as their chemical defenses, for example, those that help them cope with herbivorous insects (Rodriguez-Saona et al., 2011). Evans (1993) indicated that the domestication process is an anthropogenic and directional selection, and this selection changes the physical or chemical traits of plants that have a strong effect on other plants, insects and their natural enemies. Therefore, crop domestication can affect the structure of insect assemblages (populations in an ecosystem) associated with host-plants and their interactions. For example, Chen et al. (2013) reported that cultivated rice had $50 \%$ fewer taxa of associated insects than wild rice and that there were losses in taxonomic species. Moreover, in wild rice, 173 taxa were found that were not found in cultivated rice, whereas cultivated rice supported only 23 taxa. For example, Chen and Bernal (2011) reported that the arthropod diversity was significantly higher in cultivated rice than in wild plants ( $21.52 \pm 0.32$ vs. $20.24 \pm 0.39$ species/ plot) when cultivated and wild rice species were compared. Murtilla, Ugni molinae Turcz (Myrtaceae), is an endemic and polymorphic shrub from Chile and is distributed from Region del Maule to Region del General Carlos Ibáñez del Campo (Seguel et al., 2000; Seguel and Torralbo, 2004). In Chile, there is a strong economic interest in the production of $U$. molinae due to the presence of antioxidant compounds, specifically flavonoids present in the leaves and fruits, and this plant has an incipient berry used as food (Rubilar et al., 2011). Considering these facts, researchers at the Experimental Station INIA Carillanca (Region of La Araucanía, Chile) have been domesticating this species for approximately 20 years, generating a domestication process from wild to cultivated conditions. There are no studies comparing the insect diversity associated with wild and cultivated murtilla plants. Therefore, the study of insects associated with U. molinae plants, both cultivated and wild, could be an excellent biological tool to show changes in the insect community associated with the domestication process. According to the aforementioned information, domestication could increase the taxonomic assemblage and damage index but decrease the insect diversity in cultivated plants. Therefore, the objectives of this report were to compare insect assemblages associated with both wild and cultivated U. molinae plants, determine the effects of domestication on herbivory and evaluate the effect of the domestication on insect diversity.

\section{Materials and methods}

\section{Sampling area}

Seven cultivated ecotypes of U. molinae under the domestication process at INIA-Tranapuente, an experimental field near Puerto Saavedra (Region of La Araucanía, Chile, $38^{\circ} 45^{\prime} \mathrm{S}, 73^{\circ} 21^{\prime} \mathrm{W}$ ), and their respective wild parents populations were considered for the insect survey. The ecotypes selected were 08-1, 12-1, 14-4, 18-1, 19-1, 22-1 and $23-2$, and their corresponding wild parents were selected from those showing a similar size (around $1 \mathrm{~m}$ tall), architecture, and phenology and were sampled from Caburgua $\left(39^{\circ} 11^{`} \mathrm{~S}, 71^{\circ} 49^{\prime} \mathrm{W}\right)$,

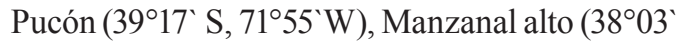
S, $73^{\circ} 10^{\prime} \mathrm{W}$ ), Soloyo ( $38^{\circ} 35^{`} \mathrm{~S}, 72^{\circ} 34^{\prime} \mathrm{W}$ ), Porma

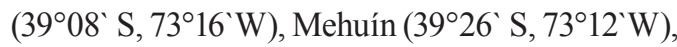
and Queule ( $\left.39^{\circ} 23^{\prime} \mathrm{S}, 73^{\circ} 12^{\prime} \mathrm{W}\right)$. The sampling considered five repetitions of a whole plant per cultivated ecotype and wild locations. The survey and samplings were carried out between December 2012 and October 2013 every two months. Fertilizer was applied annually on cultivated plants according to a soil analysis and consisted of 80,44 , and $43 \mathrm{~g}$ per plant of nitrogen, $\mathrm{P}_{2} \mathrm{O}_{5}$, and $\mathrm{K}_{2} \mathrm{O}$, respectively. Pest control was carried out using Karate (lambda-cyhalothrin; Syngenta, Greensboro, NC, USA), at a dose of 1 to $2 \mathrm{~mL}$ $\mathrm{L}^{-1}$ of water, or Lorsban 4E (chlorpyrifos; Dow AgroSciences, Indianapolis, IN, USA), at a dose of $1 \mathrm{~mL}^{\text {plant }}{ }^{1}$ (one to two applications during the 
year), according to the incidence of cutworms. To avoid residual toxicity, all samples were collected at least 7 days after insecticide applications.

\section{Insect survey and insect diversity indexes}

Insect specimens were collected manually with a mouth aspirator between 900 and $1800 \mathrm{~h}$ from leaves, stems, flowers and fruits, and each whole plant was visually and manually examined for $5 \mathrm{~min}$. After completing the inspection of each individual plant, the soil surface below the canopy was examined (Knott et al., 2006). The collected insects were those that used the plant as a host and those that visited the plant at the sampling time. The captured insects were stored in Khale's solution (water (56.6\%), ethanol (28.3\%), acetic acid (3.8\%) and formaldehyde (11.3\%)), and the species were determined in the laboratory under an optical microscope (Olympus SD 30) using key books reported by Artigas (1994). Furthermore, the relative abundance index was estimated as the number of individuals per plant (Samo et al., 2008), and a relative abundance index was obtained for each sampled species. In addition, the diversity indexes of both wild and cultivated plants were calculated as follows: Margalef index: $\mathrm{D}_{\mathrm{mg}}=\mathrm{S}-1 / \ln (\mathrm{N})$ where $\mathrm{S}=$ number of species in a sample and $\mathrm{N}=$ total number of organisms in the sample; the Shannon index: $\mathrm{H}^{\prime}=-\Sigma$ pi $\log _{2}$ (pi); and the Simpson index: $\mathrm{D}=1 / \Sigma(\mathrm{pi})^{2}$ where $\mathrm{pi}=\mathrm{ni} / \mathrm{N}$ $\mathrm{ni}=$ species abundance and $\mathrm{N}=$ total number of organisms in the sample (Samo et al., 2008).

\section{Evaluation of leaf damage}

Leaves were collected from both cultivated ecotypes and wild locations (12 leaves per plant) from the four cardinal directions at different heights of the plant. The vegetal material was stored in paper bags, transported to the Laboratory of Química Ecológica of the Universidad de La Frontera and stored at $-20{ }^{\circ} \mathrm{C}$ until their evaluation. The damage percentage was calculated by evaluating the foliar area using the Image J 1.42 software (Wayne Rasband National Institutes of Health, USA). The damage was categorized according to the methodology proposed by Dirzo and Dominguez (1995) as follows: $0=$ intact; $1=1-6 \% ; 2=$ $6-12 \% ; 3=12-25 \% ; 4=25-50 \% ; 5=50-100 \%$. The index damage by plant was calculated by means of the formula reported by Rodriguez-Auad and Simonetti (2001): DI $=\Sigma \mathrm{ni}(\mathrm{ci}) / \mathrm{N}$, where $\mathrm{ni}=$ number of leaves in the $\mathrm{i}^{\text {th }}$ category of damage, $\mathrm{ci}=$ midpoint of each category, and $\mathrm{N}=$ total number of leaves.

\section{Statistical analysis}

The statistical software Statistix 10 (Tallahassee, Florida, United States of America) was used to analyze the damage index and the total number of insects in both wild and cultivated plants. Damage indexes were analyzed by a fully nested hierarchical random analysis of variance, using domestication degrees as the main factor and temporal variation as a nested factor within domestication degree (wild and cultivated). Posterior LSD Fischer tests were used for comparisons among groups. Finally, for contrasting the damage indexes between cultivated plants and their wild counterparts, $t$-tests were used. To analyze the number of insects, a chi square test was performed. The data were natural-log transformed to meet the assumptions of normality and homogeneity of variance. Values of $\mathrm{P} \leq 0.05$ were considered significant. The results are expressed as means and their corresponding standard errors.

\section{Results}

\section{Insect survey}

A total of 243 insects were collected, 188 individuals from wild plants (77.3\%) and 55 from cultivated plants (22.7\%) (Figure 1A). The several insect orders collected were Coleoptera (28.2\%), Diptera (17.9\%), Hemiptera (10.2\%), Hymenoptera 
(12.8\%), Lepidoptera (10.2\%), Neuroptera (2.56\%), Orthoptera (5.12\%), Homoptera (7.69\%), Blattodea (2.56\%), and Phasmatidae (2.56\%). Coleopterans were represented by Curculionidae (18.18\%), Tenebrionidae (12.82\%), Carabidae (7.69\%), Scarabaeidae and Cerambycidae (5.12\%), and finally, Chrysomelidae, Meloidae, Cupedidae, Bostrichidae, Bruchidae and Coccinellidae (2.56\%). Dipterans were represented by Asilidae (30\%), Tabanidae (20\%) and Cecidomyiidae, Dolichopodidae, Muscidae, Tipulidae, and Calliphoridae (10\%). For Hemipterans, Lepidopterans and Homopterans, the percentages were distributed equally in the families shown in Table 1. For Neuropterans, Blattodea and Phasmidae, only one family was represented, as shown in Table 1. Orthopterans were represented by Acrididae
(66.66\%) and Tettigoniidae (33.33\%). Finally, Hymenopterans were represented by Formicidae, Ichneumonidae and Apidae (25\%) and Pompilidae and Vespidae (12.5\%). Insect assemblages were lower in wild parents than in the respective cultivated ecotypes, except for wild plants located in Pucón and Porma (Figure 1A). The dynamics of both cultivated and wild murtilla plants is shown in Figure 2A. The maximum insect assemblages can be observed between October and December for wild plants. In contrast, the assemblages were more stable throughout the year and were lower than that found for wild plants. Moreover, based on field observation (wild species), it was possible to identify symptoms that indicated the presence of a phytoplasm called witch's broom disease. Symptoms were present in all wild locations.
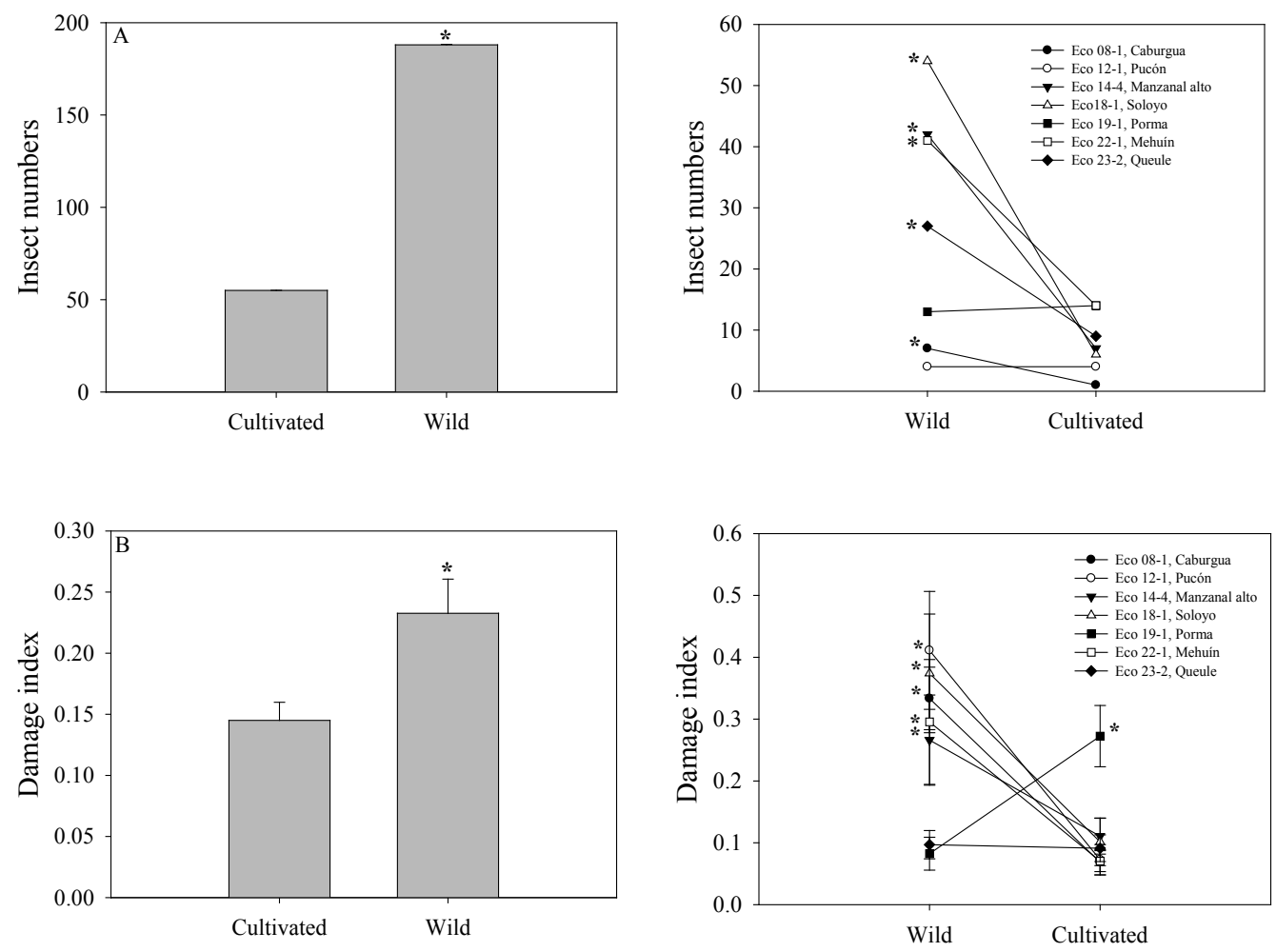

Figure 1. Results from the insect survey: A) insect numbers in wild and cultivated plants (left) and the different agroecological areas (right), B) damage index in wild and cultivated plants (left) and individual damage index comparison between wild and cultivated plants based on ecotype and geographical area (right). 


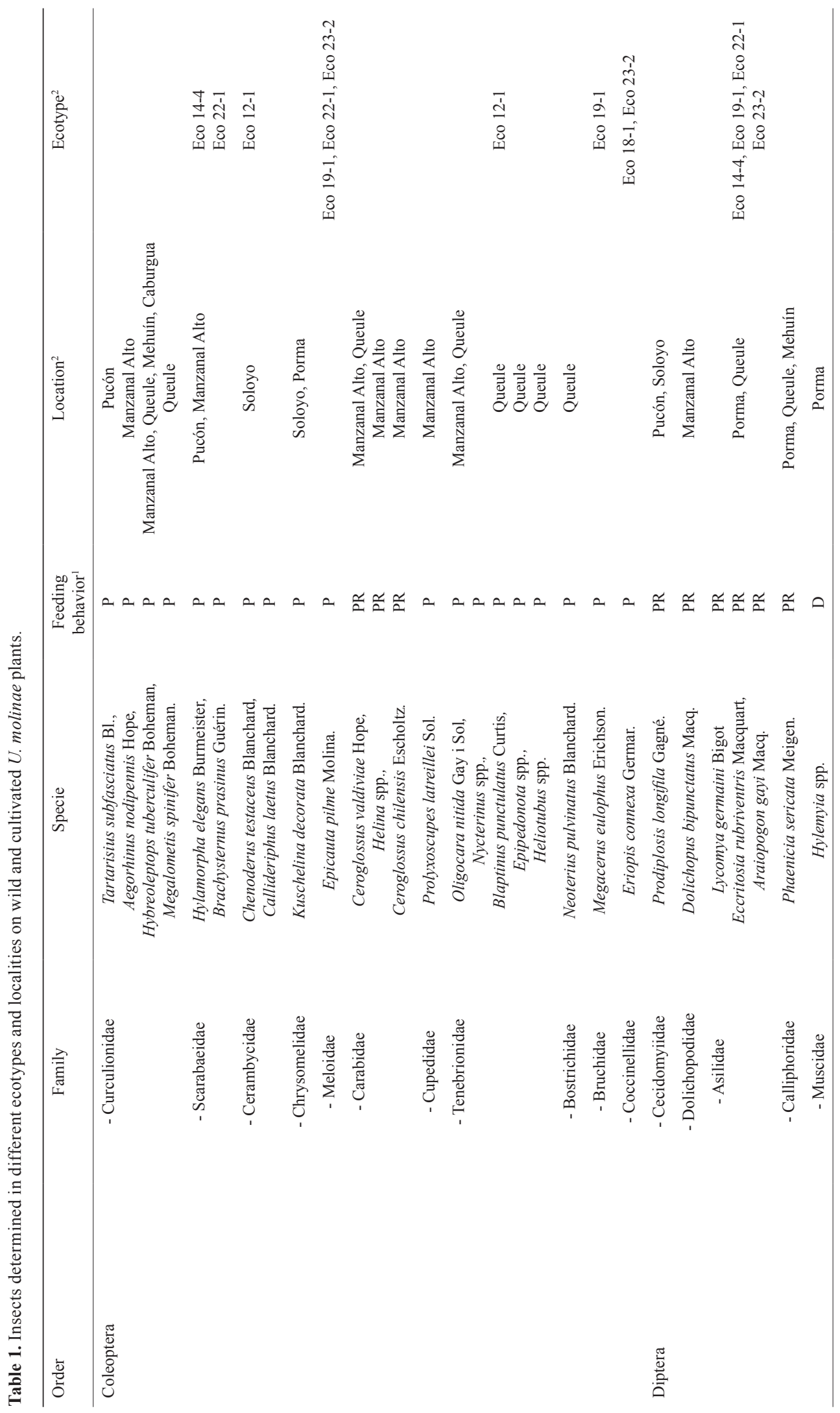




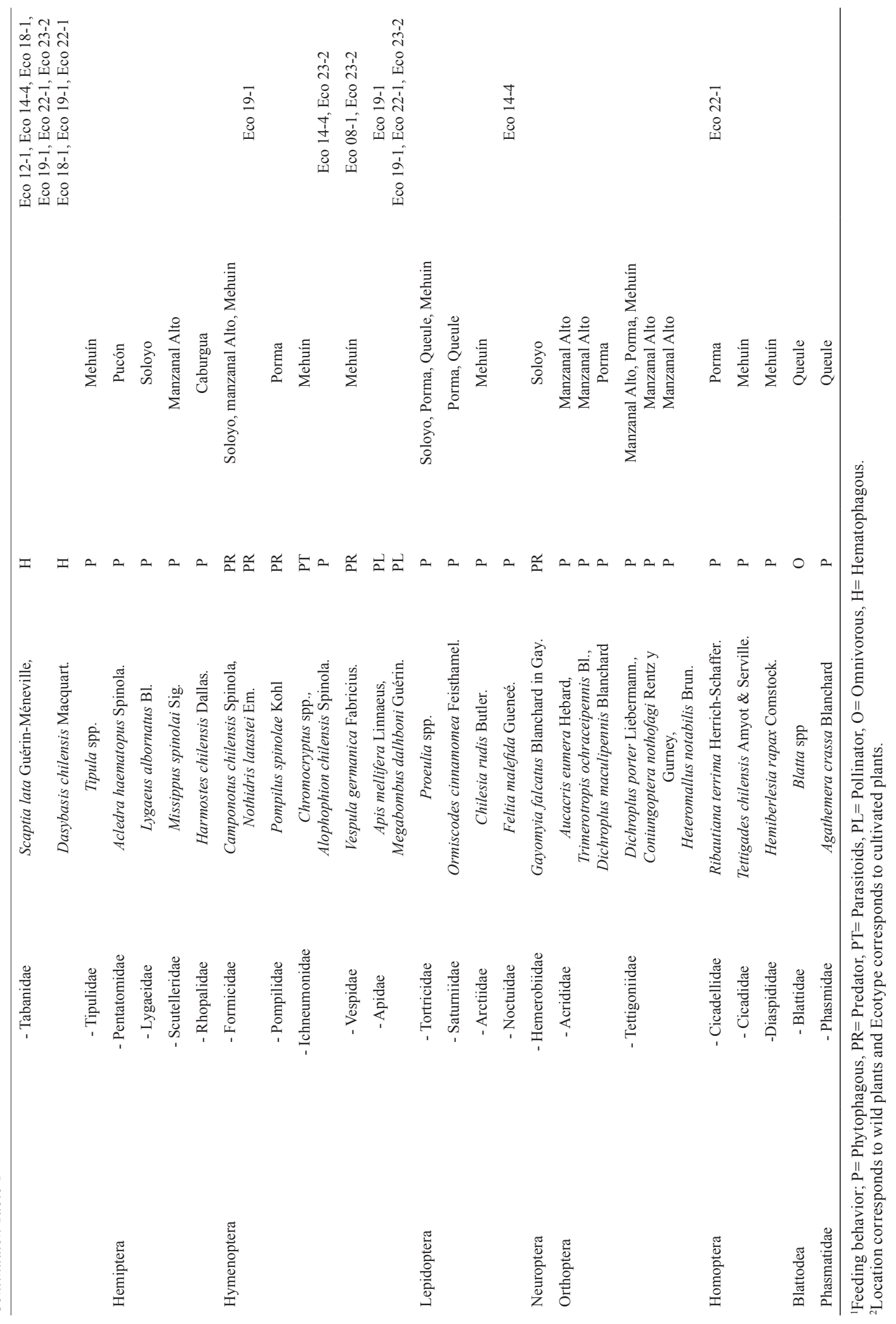




\section{Damage index evaluation}

In general, the wild species presented significantly higher insect assemblages than cultivated plants according to $t$-tests $(\mathrm{P} \leq 0.05)$ (Figure 1A). For instance, Caburgua, Manzanal Alto, Soloyo, Mehuín and Queule presented insect assemblages higher than their respective cultivated counterparts (Figure 1B). The temporal variation of the damage index that was calculated for wild and cultivated murtilla plants showed a similar pattern throughout the year. The interaction between months and the domestication effect was a significant effect $\left(\mathrm{F}_{12,5446}=16.49 ; \mathrm{P} \leq 0.001\right)$ on the damage index in murtilla plants. Similarly, the domestication effect was a significant effect $\left(\mathrm{F}_{1,5446}=28.34\right.$; $\mathrm{P} \leq 0.001)$ on the damage index generated in murtilla plants, as shown in Table 2 and Figure $2 \mathrm{~B}$. The highest damage index levels were found in December for cultivated and wild plants (0.9 and 1.2, respectively). However, in this month, the damage index of wild plants was significantly higher $(\mathrm{P} \leq 0.05)$ than that of their cultivated counterparts.

\section{Insect diversity}

The Shannon index was higher in wild plants (5.15) than in cultivated plants (4.40), suggesting that wild species have greater diversity than cultivated species (Table 3). Moreover, in the Margalef index (Table 3), there was difference between cultivated plants (6.98 vs. 12.98) and wild plants, which indicated that there is greater species richness in wild $U$. molinae plants. However, there was a higher number of insects in wild species than in cultivated species (Figure 1A). Furthermore, differences were observed in wild and cultivated plants according to the Simpson index (19.04 vs. 15.04).

Table 2. Summary results of two-way ANOVAs for the effects of temporal variation on the damage index in murtilla, Ugni molinae.

\begin{tabular}{lcccc}
\hline Parameter & Variable & $d f^{1}$ & $F$ & $P$ \\
\hline Damage index & Domestication degrees & 1,5446 & 28.34 & $\leq 0.001$ \\
& Domestication ' Months (within domestication) & 12,5446 & 16.99 & $\leq 0.001$ \\
& Residual & 5446 & & \\
& Total & 5459 & & \\
\hline
\end{tabular}

${ }^{1}$ Degrees of freedom: numerator, error.
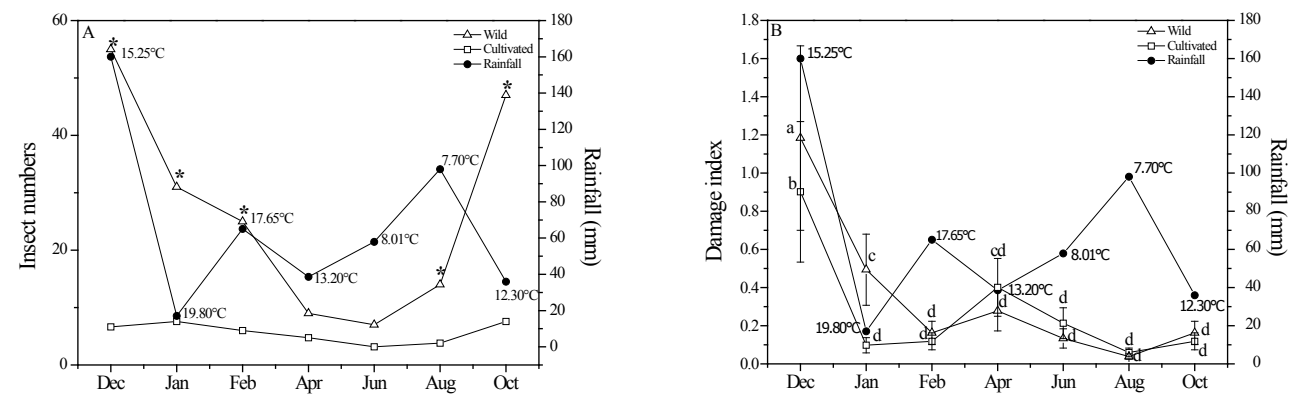

Figure 2. The effect of temporal variation, rainfall and temperatures on insect number (A) and damage index (B) in wild and cultivated murtilla, Ugni molinae, from December 2012 to October 2013. Temperatures and rainfall are expressed as the mean between Temuco and Valdivia. *mean differences according to the Chi Square test and different letters mean significant differences based on the LSD Fischer test $(\mathrm{P} \leq 0.05)$. 
Table 3. Diversity parameters evaluated in both wild and cultivated plants of $U$. molinae from December 2012 to June 2013.

\begin{tabular}{lcc}
\hline Parameters & Wild & Cultivated \\
\hline Species richness ${ }^{1}$ & 69 & 29 \\
Total individuals & 188 & 55 \\
Relative abundance $(\%)^{2}$ & 77.36 & 22.64 \\
Margalef index & 12.98 & 6.98 \\
Shannon index & 5.15 & 4.40 \\
Simpson index & 19.04 & 15.04 \\
\hline
\end{tabular}

${ }^{1}$ Number of species for wild or cultivated plants.

${ }^{2}$ Percentage of the total number of individuals found in both wild and cultivated domestication stages.

\section{Discussion}

The phytophagous insect associated with $U$. molinae has been studied previously by Aguilera et al. $(2005,2009)$. Nevertheless, there are no specific reports about insect pests in U. molinae related to the domestication process. Aguilera et al. $(2005,2009)$ reported 22 and 10 species associated with murtilla, respectively. These insects were collected in the 2003-2004 season in the Region of La Araucanía and Region de Los Lagos and correspond to only phytophagous insects. Furthermore, the 2005-2006 season was also evaluated by Aguilera et al. (2009), who added new species to the identified phytophagous insects related to $U$. molinae plants. In the present research, we identified approximately 60 insect species in wild and cultivated murtilla plants from December 2012 to October 2013 that had not been reported previously (Table 1). The results found in this study could be helpful regarding information about the variation in the insect assemblages in crops that are subjected to domestication or anthropogenic intervention. Indeed, despite its short history of domestication ( $<20$ years), the high number of insects observed in association with $U$. molinae suggests that once this crop completes its domestication process, it could be affected by a wide spectrum of phytophagous insects. These insects could produce several types of damage due to their defoliating or sucking feeding behaviors, or insects may cause damage when they oviposit, as is the case with Tettigades chilensis Amyot \& Serville (Hemiptera: Cicadidae) found in this survey. In the last 10 years, several authors have developed a theoretical framework for understanding the evolution of plant defenses that protect against herbivores. Bautista et al. (2012) has suggested that the degree of resistance to herbivores reflects a compromise between the benefits of reduced herbivory and the costs of diverting resources from other functions to resistance. Crawley (1997) reported that plant morphology can influence insect acceptability directly, either by providing a suitable visual cue or by influencing the ability of insects to walk on or bite into the tissue. Furthermore, most phytophagous insects are confined to certain plant parts, which is determined by the physical and chemical attributes to which the insects respond. In addition, the presence (or absence) of chemical barriers, such as secondary metabolites, determines the range of insect attacks. However, this aspect was not addressed in this investigation. Moreover, according to Artigas (1994), Hylamorpha elegans is one of the most dangerous species in wheat from the Region of Bío Bío to Region of Los Lagos, Chile, generating plant losses that reach $80 \%$. Although their main hosts are gramineous, $H$. elegans could be using U. molinae as a second host. In addition, one highlight in our findings is Proeulia spp, which, according to Gonzalez (2003), shows increased presence in fruits related to anthropogenic intervention. Furthermore, species such as P. chrysopteris (Butler) are quarantined in the USA and are prohibited in the shipping of kiwi and grapes. Another species that was found in the present report was Aegorhinus nodipennis; this curculionid has been reported mainly in association with blueberries, peaches, plums and apples (Aguilera et al., 2011). A. nodipennis could represent a potential threat to U. molinae due to its similarity to blueberries. Furthermore, in the present research, we found a specific association between witch's broom disease and 
murtilla, the most common and destructive disease of the foliage in murtilla plants. The main characteristic of this disease is an uncontrolled branching associated with biotic factors. Moreover, this plant disease is characterized by a reduction in the size of shoots and overgrowth of these; the leaves become smaller and tighten acquiring a reddish to yellowish color, not allowing the development of fruits and when they reach some develop, have a bad taste (Andrade et al., 2009). It is transmitted by Cicadellidae (Hemiptera), particularly by Carelmapu aureonitens Linnavuori \& De Long and Carelmapu ramosi Linnavuori. We found witch's broom in all seven wild locations, making it a decisive factor in determining the presence of Carelmapu spp. Moreover, Aguilera et al. (2009) reported that this disease was found in some experimental plots cultivated with $U$. molinae in the Region of $\mathrm{La}$ Araucanía. The Margalef index for wild species was higher (12.98) than other reports for cultivated ecosystems. For instance, in barley crops, this index ranged from 0 to 0.96 (Abay et al., 2009). The Margalef index for wild U. molinae plants agreed with Lexerod and Eid (2006), where the range varied from 4.09 to 8.47 . Nevertheless, the higher richness according to the Margalef index was found in wild plants. This finding could be associated with the loss of chemical defenses due to the domestication process. Overall, for both wild and cultivated plants, the diversity indexes were higher than two considered as moderate. This index is variable from less than 1 (Aslam, 2009) to more than 8 (Lexerod and Eid, 2006). Therefore, these values are related to a medium level of diversity for cultivated plants and a high level of diversity for wild plants. The Shannon indexes were higher than those reported for farmland wheat (Chateil et al., 2013), where the index ranged from 0.2 to 1.4 . In relation to wild plants, the insect diversity of our data was lower than the Shannon index reported by Bibi and Ali (2013) in a wildlife sanctuary (Pakistan), where the index ranged from 3.31 to 3.39 for the fauna of this landscape. In addition, cultivated plants have a low Shannon index (4.40), mean- ing that cultivated plants are more affected by anthropogenic management (Takhelmayum and Gupta, 2015). Moreover, the Simpson index showed values from 15.04 in cultivated plants to 19.04 in wild plants, meaning that there was high diversity in both sites. As the first approach, the domestication process and the management of a monoculture can be responsible for the loss of or decrease in diversity in cultivated species of $U$. molinae. Seguel and Torralbo (2004) indicated that Bombus spp. is the principal pollinators of $U$. molinae, and for this reason, the loss of diversity through the domestication process or monoculture can signify a decrease in pollination. Future research will be focused on the effects of secondary metabolites on the insect assemblages on wild and cultivated U. molinae plants. We detected changes in the community and numbers of the insect assemblages, the diversity indexes and also the damage indexes, which could suggest that the domestication of murtilla has altered the insect community in plants under agricultural management compared to plants in wild populations. We think that further experiments should continue to explore how domestication can affect these parameters in a controlled environment through a common garden. This is the first approach relating insect assemblages, diversity and damage indexes in wild and cultivated $U$. molinae plants. Future investigations will determine the effect of domestication on the chemical defenses in murtilla plants. Nevertheless, a single location in an area where all ecotypes were growing together was compared with wild parents in seven different locations. This setup could bias the evaluated diversity and damage variables to detect lower values in the single locality condition. Currently, there are few fields in which this crop is cultivated, and the only location where all the cultivated plants related to their original counterparts are reported is the Experimental Station INIA-Tranapuente. Therefore, this first approach is subject to environmental factors, which will be avoided in the future through a common garden experiment for both wild and cultivated plants. 


\section{Acknowledgments}

We thank the Graduate Natural Resources Program of the Universidad de La Frontera (Temuco, Chile). Financial support for this research was supplied by the CONICYT scholarship (21110939) and FONDECYT (Project 1141245). Supported (partially) by Dirección de Investigación, Universidad de La Frontera.

\section{Resumen}

M. Chacón-Fuentes, M. Lizama, L. Parra, I. Seguel y A. Quiroz. 2016. Diversidad, composición de la comunidad de insectos e índice de daño, en murtillas silvestres y cultivadas. Cien. Inv. Agr. 43(1):57-67. La domesticación vegetal es un proceso en el cual las plantas pueden disminuir su nivel de defensas químicas para combatir herbívoros. Algunas de las posibles consecuencias podrían reflejarse en un incremento en el número y en la diversidad de insectos. Por lo tanto, se realizó un "survey" para comparar el índice de daño y la diversidad de insectos en plantas cultivadas y silvestres de murtilla (Ugni molinae). La principal interrogante de este trabajo fue: ¿La domesticación en plantas de murtilla, disminuirá la diversidad e incrementará el índice de daño y la comunidad de insectos? El objetivo de esta investigación fue comparar la población de insectos asociada a plantas silvestres y cultivadas además de analizar su variación durante el año. Siete ecotipos y sus correspondientes contrapartes silvestres fueron seleccionadas para este estudio. Los resultados mostraron un mayor número de insectos en plantas silvestres $(77,35 \%)$ vs. $(22,7 \%)$ cultivadas. El índice de daño fue mayor en plantas silvestres $(0,23)$ comparada con plantas cultivadas. El índice de Margalef mostró la mayor riqueza de insectos en plantas cultivadas. Sin embargo, el índice de Shannon fue mayor (5.15) en plantas silvestres. Además, cerca de 60 especies de insectos fueron determinadas. Se detectaron cambios en la comunidad de insectos, índices de daño y diversidad que podrían sugerir que la domesticación en murtilla ha alterado la comunidad de insectos.

Palabras clave: Diversidad de insectos, domesticación, índice de daño, Ugni molinae.

\section{References}

Abay, F., A. Bjørnstad, and M. Smale. 2009. Measuring on farm diversity and determinants of barley diversity in Tigray. Northern Ethiopia 1: 44-66.

Aslam, M. 2009. Diversity, species richness and evenness of moth fauna of Peshawar. Pakistan Entomology 31: 91-102.

Aguilera, A., M. Ellena, I. Seguel, A. Montenegro, J. San Martin, and L. Torralbo. 2005. Primeras determinaciones de insectos y otros invertebrados fitófagos asociados a murta, Ugni molinae Turcz (Myrtaceae) en el sur de Chile. Idesia 23: 7-11.

Aguilera, A., M. Ellena, I. Seguel, A. Montenegro, J. San Martin, L. Torralbo, and R. Rebolledo. 2009.
Nuevos registros de insectos asociados a murta o murtilla (Ugni molinae Turcz) en Chile. Idesia 27: 33-37.

Aguilera, A., J. Guerrero, and R. Rebolledo. 2011. Plagas y Enfermedades del Avellano Europeo en La Araucanía. Ediciones Universidad de La Frontera. Temuco, Chile. 126 pp.

Andrade, N., M. Villagra, and N. Arismendi. 2009. Evidencias microscopicas y moleculares de la presencia de fitoplasmas en plantas de murtilla (Ugni molinae Turcz) afectadas por "escoba de bruja”. Tropical Plant Pathology 34: 245-249.

Artigas, J. 1994. Entomología económica, insectos de interés agrícola, forestal, médico y veterinario (nativos, introducidos, y susceptibles de ser in- 
troducidos). Vol. 1-2. Concepción, Chile. pp. 1126-943.

Bautista A, F. Parra Rondinel, and F. Espinosa-García. 2012. Efectos de la Domesticación de Plantas en la Diversidad Fitoquímica. p. 253-267. In: J.C. Rojas and E.A. Malo (eds.). Temas Selectos en Ecología Química de Insectos. El Colegio de la Frontera Sur. México.

Bibi, F., and Z. Ali. 2013. Measurement of diversity indices of avian communities at Taunsa barrage wildlife sanctuary, Pakistan. Journal Animal Plant Science 23: 469-474.

Chateil, C., I. Goldringer, L. Tarallo, C. Kerbiriou, I. Le Viola, J. Ponge, S. Salmon, S. Gachet, and E. Porcher. 2013. Crop genetic diversity benefits farmland biodiversity in cultivated fields. Agriculture Ecosystem and Environment 171: 25-32.

Chen, Y., G. Langelloto, A. Barrion, and N. Cuong. 2013. Cultivation of domesticated rice alters arthropod biodiversity and community composition. Annals of Entomological Society of America 106: 100-110.

Chen, Y., and C. Bernal. 2011. Arthropod diversity and community composition on wild and cultivated rice. Agricultural and Forest Entomology 13: $181-189$.

Crawley, M. 1997. Life history and environment. Plant Ecology 73: 141-165.

Dirzo, R., and C. Dominguez. 1995. Plant-Herbivore in Mesoamerican tropical dry forest. p. 304-325. In: Bullock, S.H., H.A. Mooney and E. Medina (eds.). Seasonally dry tropical forests Cambridge University Press. New York, USA.

Evans, L.T. 1993. Crop Evolution, Adaptation, and Yield. Cambridge University Press. New York, USA. 500 pp.

Gepts, P. 2014. Domestication of plants. Encyclopedia of Agriculture and Food Systems 2:474-486.

Gonzalez, H. 2003. Las polillas de la fruta en Chile (Lepidoptera: Tortricidae; Pyralidae) Serie Ciencias Agronómicas No 9. Santiago, Chile. 188 pp.
Knott, J., M. Boetel, and P. Glogoza. 2006. Estimating Lygus lineolaris (Heteroptera, Miridae) population densities in sugarbeet. Journal of Sugar Beet Research 43: 15-25.

Lexerod, L., and T. Eid. 2006. An evaluation of different diameter diversity indices based on criteria related to forest management planning. Forest Ecology and Management 222: 17-28.

Rodriguez-Auad, K., and J. Simonetti. 2001. Evaluación de la folivoria, una comparación de dos métodos. Ecología en Bolivia 36: 65-69.

Rodriguez-Saona, C, N. Vorsa, A. Singh, J. JohnsonCicalese, Z. Szendrei, M. Mescher, and C. Frost. 2011. Tracing the history of plant traits under domestication in cranberries: potential consequences on anti-herbivore defences. Journal of Experimental Botany 62: 2633-2644.

Rubilar, M., C. Jara, Y. Poo, F. Acevedo, C. Gutierrez, J. Sineiro, and C. Shene. 2011. Extract of maqui (Aristotelia chilensis) and murta (Ugni molinae Turcz), Sources of antioxidant compounds and alfa-glucosidase/alfa-amylase inhibitors. Journal of Agricultural and Food Chemistry 59: 1630-1637.

Samo, J., S. Garmendia, and J. Delgado. 2008. Introducción práctica a la Ecología. Pearson Educación, S.A., Madrid, España. 248 pp.

Seguel I., E. Peñaloza, and N. Gaete. 2000. Colecta y caracterización molecular de germoplasma de murta (Ugni molinae Turcz.) en Chile. Agro Sur 28: 32-41.

Seguel, I., and L. Torralbo. 2004. Murtilla, El berry nativo del Sur de Chile. Revista Tierra Adentro 57: 20-25.

Takhelmayum, K., and S. Gupta. 2015. Aquatic insect diversity of a protected area, Keibul Lamjao, National Park in Manipur East India. Journal of Asia-Pacific Entomology 18:335-341.

Turcotte, M, N., Turley and M. Johnson. 2014. The impact of domestication on resistance to two generalist herbivores across 29 independent domestication events. New phytologist 1-11. 
